\title{
ICТОРІЯ УКРӒ̈НИ
}

UDC 94(477.8): 351.742 "1929/1971"

DOI: doi.org/10.21272/shaj.2018.i31.p.25

YAROSLAV M.ANTONIUK

$\mathrm{PhD}$ (History), Branch State Archive of Security Service of Ukraine (Ukraine)

\section{SECURITY SERVICE RESISTANCE TO THE ECONOMIC AND FINANCIAL MISUSES IN OUN AND UPA UNDERGROUND NETWORKS}

\begin{abstract}
The article studies a resistance to economic and financial misuses in the Organization of Ukrainian Nationalists (hereinafter - OUN) and the Ukrainian Insurgent Army (hereinafter - UPA) underground networks, on the basis of unknown and recondite documents. It was proven that such criminal occurrences were always present in the Ukrainian liberation movement at all its stages. The first instances of corruption were recorded in 1929 among the founders of the OUN. Nevertheless, the economic and financial misuses in the Ukrainian nationalist underground activities had never gained significant proportions. The corruption size appeared to be much smaller and insignificant, comparing to one in the German occupation administration. Moreover, it could not had been compared with the total corruption dominance which was present in the Soviet society. It was clarified that with the beginning of the OUN expanding the branched underground network in 1942, their Security Service, which had been recently established, tried various methods to fight against economic and financial overuses in OUN underground environment.
\end{abstract}

Although, the fight against corruption has never been placed to a prominent position in the work flow of the underground organizations. It had always been one of the aspects of more important activities of the Security Service (SB). The main object of the anti-corruption investigations was to control the activity of economic referents, who were responsible for managing the organization finances. The suspects were subjected to relevant investigation actions, legal procedures and evidence collections. The punishment of the convicted depended on the severity of the crime and the circumstances of the commission. The suspects who had been proved to commit corruption crimes, predominantly, were executed by the death penalty performed by shooting. In addition to that, the suspected could had been found guilty in absentia. Its execution was carried out under any convenient conditions.

After the UPA was founded in the spring of 1943 and the development of its Zapillya (military-civilian administration) started in the autumn of the same year, the Security Service resistance to the corruption occurrences intensified and became more complicated. A large number of normative documents were created which severely punished not only those connected to economic, but also ordinary insurgents for any property fraud. Leaders who tolerated corrupt crimes in their area of responsibility were significantly lowered in their positions. Those who directly committed any corruption crimes were shot or hanged. For trivial economic crimes the insurgents were punished by their position lowering, higher physical activity during their service or public beating. The $S B$ did not left unattended the property acquired in combat operations. Those who were accused of its theft, even including the $S B$ employees, were executed.

The anti-corruption measures of the Overseas OUN and UPA Security Service (namely the one emigrated to the Western countries) were taken and operated withing the scope of local legislation. In this regard, it became considerably humane. The Security Service investigations concerned only individual executives who plundered funds from organizational cash desks.

Keywords: misuses, OUN and UPA underground, Security Service (SB), economic referent, finance referent, corruption. 
АНТОНЮКЯ.М.

Кандидат історичних наук, Галузевий державний архів Служби безпеки України (Україна)

\title{
ПРОТИДІЯ СЛУЖБИ БЕЗПЕКИ ГОСПОДАРСЬКО-ФІНАНСОВИМ ЗЛОВЖИВАННЯМ В ПІДПІЛЛІ ОУН ТА УПА
}

\begin{abstract}
Анотація. У статті на основі невідомих і маловідомих документів досліджено протидію зловживанням в господарсько-фінансовій діяльності підпілля Організаиії украӥнських націоналістів (далі - ОУН) та Української повстанської армї (далі - УПА). Доведено, щуо головні “антикорупчійні" функції виконувала Служба безпеки. Керівники підпілля, які допустили корупиійні злочини своїх підопічних, суттєво понижувалися в посаді. Безпосередніх винуватиів зловжсивань страчували. За дрібні господарчі злочини карали додатковими навантаженнями під час служби.
\end{abstract}

Ключові слова: зловживання, підпілля ОУН та УПА, Служба безпеки (СБ), господарський референт, фінансовий референт, корупція.

\section{АНТОНюК Я.Н.}

Кандидат исторических наук, Отраслевой государственный архив Службы безопасности Украины (Украина)

\section{ПРОТИВОДЕЙСТВИЕ СЛУЖБЫ БЕЗОПАСНОСТИ ХОЗЯЙСТВЕННО- ФИНАНСОВЫМ ЗЛОУПОТРЕБЛЕНИЯМ В ПОДПОЛЬЕ ОУН И УПА}

Аннотация. В статье на основе неизвестных и малоизвестных документов исследовано противодействие злоупотреблениям в хозяйственно-финансовой деятельности подполья Организации украинских националистов (далее - ОУН) и Украинской повстанческой армии (далее - УПА). Доказано, что главные “антикоррупиионные” функции выполняла Служба безопасности. Руководителей подполья, которые допустили коррупиионные преступления своих подопечных, существенно понижали в должности. Непосредственных виновников злоупотреблений казнили. За мелкие хозяйственные преступления наказывали дополнительными нагрузками во время службь.

Ключевые слова: злоупотребление, подполье ОУН и УПА, Служба безопасности (СБ), хозяйственный референт, финансовый референт, коррупиия.

Корупція настільки ж давнє явище, як і соціальні взаємини між людьми. Ї̈̈ прояви можна віднайти в усіх періодах нашої непростої історії. Паралельно, у різних формах, йшла боротьба $з$ цим явищем. Не оминув корупційного чинника й український визвольний рух. Зокрема окремі його аспекти мали місце в діяльності підпільної мережі Організації Українських Націоналістів (далі-ОУН) та підрозділів Української Повстанської Армії (далі-УПА).

Незважаючи на значний науковий інтерес істориків до тематики протидії корупції, досі не вийшло жодної публікації, присвяченої згаданому явищу в українському визвольному русі. Приклади корупційних проявів в підпіллі ОУН, а також протидія їм згадувалися в працях: Галини Стародубець (Стародубець, 2006, 2008), Василя Даниленка (2006), Дмитра Вєдєнєєва, Геннадія Биструхіна (Вєдєнєєв, Биструхін, 2006, 2007), Ярослава Антонюка, Володимира Трофимовича (Трофимович, Антонюк, 2009), Миколи Литвина (Ливин, 2012) та Василя Ільницького (Ільницький, 2017). Однак, зважаючи на новизну теми, переважно стаття опирається на опубліковані та неопубліковані архівні документи.

Спираючись на оприлюднені документи, можна стверджувати, що поодинокі випадки фінансових зловживань в ОУН траплялися від самого початку виникнення. 
Наприклад, один з їі засновників - Ріхард Ярий, підозрювався в розкраданні майна (спекуляція кіньми) інтернованого в Чехословаччині 5-го Херсонського кінного полку Армії УНР, а згодом - привласненні частини коштів, які німці виділяли провіднику ОУН Євгену Коновальцю (ГДА СБУ. Ф. 13. Спр. 372. Т. 34: 51-59).

12 травня 1931 р. у середовищі української еміграції стався гучний фінансовий скандал. Комітет “Об’ єднання”, який зібрав на допомогу ОУН в США та Канаді понад 24976 доларів, піддався нападкам з боку діячів Українського національно-демократичного об”єднання (УНДО). Через статті у газетах “Народна Воля” та “Діло” вони заявляли, що пожертви розікрали. У відповідь на це Комітет “Об'єднання” опублікував в газеті “Свобода" детальний звіт про розподіл зібраних коштів. Як згодом виявилося, дійсною причиною нападок згаданих діячів, стало їх усунення від розподілу зібраних діаспорою коштів (Мірчук, 2007: 386-387).

Проте, більшість випадків господарських зловживань серед оунівців мали незначний характер. Більше того, частина з них була пов'язана з таємним фінансуванням підпілля. Так, співробітник львівської газети "Нове Село" - Віктор Воробець, написав 17 лютого 1938 р. до головного редактора скаргу на колег-оунівців. У ній було звинувачення в проведенні “шкідливої для кооперативи господарки” (ГДА СБУ. Ф. 2. Спр. 2610: 132).

Незважаючи на періодичні появи фінансових скандалів, довгий час їм протидіяли принагідно, навздогін подіям. Змінюватися ситуація почала лише із виникненням наприкінці лютого 1939 р. та розбудовою впродовж 1940-1941 pp. Служби безпеки (далі - СБ) ОУН. Однією із їі завдань була боротьба із службовими зловживаннями в підпільній мережі.

Помітним напрямок роботи став на початку 1942 р. Сприяло цьому зосередження зусиль ОУН на господарському та військовому посиленню. Робилися запаси грошей, продуктів, необхідних речей та зброї для створення майбутніх повстанських формувань. Доступ до значних матеріальних ресурсів у поєднанні з погано налагодженим обліком та посиленою конспірацією, призвів до численних випадків зловживань. 3 цим явищем одразу розпочала боротьбу новостворена СБ ОУН. Методи її роботи не вирізнялися гуманізмом. Безпосередніх винуватців корупційних злочинів, переважно, страчували. Провідників, які вчасно не помітили зловживань підопічних, карали значним пониженням у посаді.

Наприклад, в травні 1942 р. референт СБ Крайового проводу ОУН на Західних Українських Землях (ЗУЗ) Григорій Пришляк - "Мікуша" разом із провідником ОУН Стрийської округи Адамом Куровицьким - “Сірим” розслідували розтрату провідником ОУН Журавнівського району Степаном Галариним організаційних коштів (ГДА СБУ. Ф. 5. Спр. 50970. Т. 1: 27). За вироком Революційного трибуналу арештованого на місці стратили. Натомість провідника ОУН Журавнівського повіту Матвія Демчука - “Славка”, який був зверхником Галарина, понизили у посаді (ГДА СБУ. Ф. 5. Спр. 26423. Т. 2: 20).

У випадку намагань звинуваченим уникнути слідства, його судили заочно. Так, у вересні 1942 р. співробітники СБ Крайового проводу розслідували в м. Станіслав (нині м. Івано-Франківськ) розтрату значної кількості матеріалу завідувачем майстернею шкіряних виробів Наконечним. За узгодженням із обласним проводом ОУН, його заочно засудили до смерті. За кілька днів Наконечного застрелили на малолюдній вулиці міста (ГДА СБУ. Ф. 5. Спр. 50970. Т. 1: 30).

Частину корупційних злочинів СБ вдалося розкрити завдяки внутрішнім чварам серед керівництва підпільної мережі ОУН. Так, у лютому 1942 р. організаційний референт Крайового проводу ОУН на ЗУЗ Юліан Гуляк - "Рен” усунув Василя Чижевського “Демид” з посади провідника ОУН Станіславського обласного проводу. Своє рішення він мотивував тим, що “Демид” належить до військової референтури, а отже не може займатися організаційною ділянкою роботи. На його місце призначили Кликайла - 
“Аскольда”, а Чижевського відправили формувати військовий штаб Дрогобицької обл. Вочевидь бажання помсти підштовхнуло “Демида" написати влітку 1942 р. на “Аскольда" скаргу в Провід ОУН, де повідомлялося про його зловживання службовим становищем та розтрату організаційних коштів. У відповідь на це до провідника ОУН Станіславської області відправили інспекцію в складі слідчого СБ та Крайового фінансового референта Мартинюка - "Уласа". За результатами їх роботи “Аскольда" понизили у посаді до рядового та відправили агітувати серед промислових робітників Дрогобиччини (ГДА СБУ. Ф. 6. Спр. 33286. Т. 1: 114-119; Т. 2: 198).

Наступний етап антикорупційної діяльності СБ пов'язаний із формуванням весною 1943 р. на Волині та Західному Поліссі підрозділів УПА та виникненням у серпні - вересні того ж року їі цивільно-військової адміністрації - Запілля (тилу). Реагуючи на вимогу часу, керівники різних рівнів підготували низку нормативних документів, які відповідали умовам "Революційної боротьби” (військового стану) (Литвин, 2012: 298).

Наприклад лише Група УПА “Заграва” (Рівненщина) впродовж 1943 р. видала кілька антикорупційних наказів. Два з них вийшло за підписом Івана Литвинчука “Дубового”. У першому від 15 серпня зазначалося: "Не вільно розкрадати або присвоювати організаційного майна. За кожну деградацію організаційного майна (грошей) буде каратися розстрілом" (Літопис УПА, 1999: 152). Другий від 12 жовтня застерігав: “. .. за крадіж і привласнення державного майна, а навіть і приватного чужого майна, винні будуть тяжко карані (навіть карою смерті)" (Літопис УПА, 1999: 193-194). Третій наказ від 18 жовтня був підписаний господарчим референтом Василем Морозом - “Зубатим”. У ньому зазначалося: "Всі особи працюючі в господарчій ділянці воєнної округи “Заграва”, будуть каратися найсуворішою карою воєнного часу за крадіж, саботаж, недогляд, різні комбінації і надужиття влади” (Літопис УПА, 1999: 218). Курінний Микола Свистун - “Ясен” наказував 17 грудня своїм підопічним: “За розтрату військового майна - карати буду суворо, включно до кари смерті” (Літопис УПА, 1999: 405). Аналогічне попередження 15 жовтня видав своїм підопічним господарський референт Костопільського району ОУН “Бистриця” (Літопис УПА, 2007: 494).

Розширилися й напрямки антикорупційної діяльності СБ. Розслідуванням справ відносно крадіжок та продажу повстанцями військового майна займалася Військовопольова жандармерія (ВПЖ) (Вєдєнєєв, Биструхін, 2008: 496), а корупційними злочинами в адміністрації Запілля - територіальна мережа СБ. Відомості про "розтрату і розбазарювання організаційного добра" збирав та подавав слідчим розвідувальноінформаційний відділ СБ (ДАРО. Ф. Р-30. Оп. 2. Спр. 32: 285). Інколи відповідні дані надходили у вигляді скарг самих повстанців. Так, командир кубанських козаків "Павленко" при загоні УПА імені Богуна (Турійський р-н Волинської обл.) написав 5 січня 1944 р. листа сотенному Ліхрону Гордійчуку - “Князю”. У ньому повідомлялося, що керівник ковбасні “Твердий” таємно обмінює в населення м'ясо на горілку, а також залучив до своїх “оборудок” млинарів УПА. “Павленко” просив це неподобство припинити та “зробити Твердого м'яким" (Літопис УПА, 2010: 112). Поступово налагодилася субординація у розслідуванні корупційних злочинів. У “Інформаціях клітинам СБ”, написаних 24 грудня 1943 р. Корецьким надрайонним референтом СБ Пилипом Рудим - "Громом" зазначалося, що зібраний районним СБ матеріал про випадки крадіжок серед учасників УПА, надходив через надрайон СБ до ВПЖ. Районному СБ дозволялися карати за кримінальні злочини, а усі внутрішні справи передавалися до надрайону СБ (Матеріали, 2003: 140-142).

Головним об’єктом антикорупційних розслідувань СБ були господарчі референти, які безпосередньо займалися забезпеченням підпілля. Через них проходила основна частина матеріальних ресурсів, а отже існували найбільші ризики зловживань. Крім того, 
СБ контролювала належне виконання ними своїх обов'язків. У інструкції для районних господарчих УПА від 14 лютого 1943 р. зазначалося: "Над кожним наказом прошу попрацювати та подумати, щоб не потрапити в непорозуміння й не остатись карним" (ДАРО. Ф. Р-30. Оп. 1. Спр. 22: 8). Спец-доручення Чортківського надрайону "Чорногора" тереновим господарчим від 25 серпня 1945 р. в шостому пункті "Надужиття" зобов’ язувало: “Застосовувати найсуворіші кари супроти злодійства та бандитизму. За найменший прояв крадежі, чи бандитизму з місця дати протокол та застосовувати найстрашніший вимір кари, включно до кари смерті” (ДАТО. Ф. формується).

Проте, окремі особи наважувалися діяти на власну користь. Львівський обласний господарчий референт Петро Мигаль - “Зеніт” розпорядився 25 листопада 1944 р. подати списки осіб винних в неналежному забезпечені повстанських підрозділів. Водночас повідомляв своїм підопічним, що днями за зловживання розстріляли кілька осіб. Тому господарчі, які проігнорують наказ, будуть покарані “найвищим виміром кари” (Літопис УПА, 2009: 360). Керівництво СБ ретельно стежило за звітністю у згаданих розслідуваннях та вимагало від підопічних неухильно дотримуватися інструкцій. Референт СБЗолочівської округи Роман Качан - "Гроза" написав 7 жовтня 1944 р. щодо цього “строго довірчу" інструкцію. У ній зазначалося, що стосовно усіх фактів зловживань господарчих потрібно негайно доповідати, а не розслідувати справи самостійно (Літопис УПА, 2013: 1118).

Нерідко згадані звинувачення долучалися у справі до більш важких. 11 червня 1946 р. станичного господарчого Степана Барана - “Черемху” з с. Баймаки Буського р-ну Львівської обл. звинувачували у втраті зброї, поширені панічних настроїв, а також в розтраті організаційного майна. Отримавши 1250 карбованців від проданого в червні 1945 p. односельчанкою Ганною Труш організаційного збіжжя, більшу частинугрошів передав своїй сім’ї, а за решту купував цукерки, пиво та інші речі (ГДА СБУ. Ф. 13. Спр. 376. Т. 54: 101).

Водночас фінансові зловживання, хоча й в значно менших масштабах, траплялися поміж інших керівників підпільних ланок. Наприклад, 17 серпня 1944 р. СБ Станіславівщини розслідувала справу курінного “вишкільника” УПА “Запорожця”. Поряд із підозрою у агентурній роботі на НКВС, його звинувачували в "надужитті" організаційного майна. Зокрема, без наказу свого зверхника - курінного "Грома", обміняв в угорців на худобу цигарки та інше майно. Забрав в санітарки "Оксани” літр горілки, виділений їй для медичних цілей, яку разом із своїми співробітниками випив. За горілку позичав мешканцю с. Манява Богородчанського р-ну Івано-Франківської обл. повстанського коня (ГДА СБУ. Ф. 13. Спр. 376. Т. 54: 4).

Одним із джерел корупційних зловживань окремих керівників підпілля ОУН та УПА був збір у населення коштів, продуктів, одягу та іншого майна. Незважаючи на чітко налагоджений облік та суворі покарання, знаходились особи, які зважувалися на розкрадання (Стародубець, 2008: 159-160). СБ ОУН про це чудово знала. У одному із повстанських документів зазначалося: "Господарювання народним добром $є$ до певної міри безгосподарним, марнотратним, а подекуди діються навіть зловживання" (Стародубець, 2006: 218). У “Протоколі справи дисциплінарного характеру” від 6 березня 1947 р. стосовно кур'єра Чортківського надрайону ОУН Василя Бесаги - "Чуприни" зазначалося: “Стягнув самовільно через голову сільради від гуральника 1015 крб. 3 чого 415 крб. дав сестрі, а 600 крб. забрав собі на чоботи” (ДАТО. Ф. формується).

Намагаючись запобігти розкраданню зібраного майна, передбачалося, що його роботу господарчого на місці контролюватимуть двоє “поважних, чесних мужів довір'я" (Стародубець, 2006: 218). Однак на практиці це не виконувалося. У документі з Карпатського краю ОУН зазначалося: “Часто некомпетентні люди (районні референти УЧХ, санітарки, коменданти боївок, окремі боївкарі, змобілізовані стрільці УПА) наказують станичним здавати їм бажані речі, роблять на власну руку збірки, які часто набирають 
форм грабунку. Це надзвичайно підриває наш авторитет в масах" (Ільницький, 2017: 348). В окремих випадках цьому намагалася протидіяти СБ. Так, 1 липня 1947 р. слідчі СБ району Устріччина розглядала справу брата станичного “Сича" - Василя Шимина 3 с. Бистре (нині Бещадський повіт Підкарпатського воєводства Республіки Польща). Його підозрювали у розкраданні 16 центнерів збіжжя зібраного в населення для потреб підпілля. Фігуранти розслідування путалися у показах та постійно називали інші цифри. Зрештою на “провадженні на віч" (очній ставці) відмовилися від попередніх свідчень. Як зазначалося у протоколі ч. 2., підозрюваний “крутить під час допиту”, тому справу передали для дорозслідування референту СБ “Андрію” (Ільницький, Особистий архів).

Вразливим місцем господарської мережі підпілля ОУН та УПА, особливо в радянський період, були склади-криївки. Чимало 3 них були виявлені ворогом, а частина - розкрадені місцевим населенням та самими підпільниками. У звіті СБ з Чортківської округи (Тернопільщина) від 2 грудня 1944 р. зазначалося: “Організаційне майно загально у $80 \%$ пропало. 3 того 40-45\% розікрали самі люди, а заледве $15-20 \%$ впало в руки більшовиків. Всякі намагання у напрямі стягнення розбазареного майна дали дуже мінімальні висліди, можна сказати, майже жодні. Найгірше, що крали орг. майно члени, симпатики, та їх родини і ця причина стає поважною перешкодою у дальшій роботі в цілі заготовки нових господарчих припасів. Населення про ці факти знає і не радо хоче давати, мовляв знову розкрадуть" (Літопис УПА, 2012: 632). Також згідно розслідування СБ в с. Тетильківці Шумського р-ну Тернопільської обл. вдова господарчого ОУН, яка знала місце знаходження криївки із організаційним спиртом, продавала його населенню (Літопис УПА, 2007: 140).

СБ намагалася протидіяти розкраданням складів-криївок. У наказі Ч. ІІ. референта господарчого воєнного району від 29 вересня 1943 р. зазначалося: "Не допускайте нікого до магазинів. Хто б що не брав, йому не розконспіровувати криївок. Вступ до магазинів заборонений. Крім Вашого зверхника. Коли виявиться, що хтось з Вас розбазарює державне майно, буде розстріляний” (ДАРО. Ф. Р-30. Оп. 2. Спр. 34: 147). Інструкції для співробітників СБ від липня 1946 р. ставилося завдання: “Охороняти матеріальні добра в Організації перед розтратою та знищенням” (Матеріали, 2003: 204-205). Задля цього винних у розкраданні складів-криївок виявляли та страчували. Так на території Володимирської округи ОУН (південь Волинської обл.) згадані випадки фіксували в с. Любачівка Горохівського р-ну та с. Білопіль Локачинського р-ну (Трофимович, Антонюк, 2009: 164).

Іншим важливим напрямком антикорупційної діяльності СБ була протидія розкраданням майна здобутого внаслідок бойових операцій. Зокрема згадані випадки набули поширення під час “Волинської трагедіі”'. Провідник ОУН Костопільського р-ну “Костомаров” описував 22 червня 1943 р. зловживання окремих підпільників під час антипольських акцій: "Вони зі зброєю в руках ідуть і грабують чужонаціональні, ба навіть українські села. Це роблять без відома своїх зверхників-провідників, для власної наживи. Крадуть під час акцій конфісковане боївками майно. По ліквідації польських колоній ідуть зі зброєю грабувати, розтягують будинки, меблі, інвентар...” (Літопис УПА, 2007: 248). 3 огляду на подібні випадки СБ намагалася стежити за подібними зловживаннями. Більше того, зобов'язувалася здавати господарчим майно здобуте при виконанні службових обов'язків. Зокрема про це йшлося в наказі Ч. 20 провідника ОУН на ПЗУЗ Дмитра Клячківського “Клима Савура" від 10 листопада 1943 р. (ДАРО. Ф. Р-30. Оп. 2. Спр. 32: 95).

Однак, траплялося, що й передане СБ до господарчих складів майно розкрадалося. Про один із таких випадків йшлося в донесенні провідника ОУН Рафалівського р-ну "Бена" від 9 грудня 1944 р. (Ковальчук, 2006: 58). У ньому повідомлялося, що 11 листопада того ж року боївка СБ Рафалівського району провела в с. Варани Володимирецького р- 
ну Рівненської обл. ліквідацію агентури НКВС серед місцевого населення. Майно страчених - полотно, одяг, взуття, продукти та інше, передали на зберігання кущовому Івану Бойку - “Нового”. Наступного дня комендант СБ “Богдан” відправив санітарку "Надю" для їх опису та передачі на потреби Українського Червоного Хреста. Коли ж підпільниця помітила, що частина речей зникла та заявила про це відповідальним особам, кущовий “Новий” та його кум - станичний “Заволока” 'ії висміяли. Після цього за згаданим майном прибули співробітники СБ. Вони виявили, що переданого на зберігання залишилося лише 23 метри полотна, 8 рушників, чорні штани і 4 кг гороху. За фактом розкрадання “організаційного майна” комендант СБ “Завзятий” одразу розпочав слідство. На допиті звинувачені виправдовувалися, мовляв їх сім’ї переховуються в лісі від виселення, тому вони змушені були взяти для себе частину речей. Решта, як вони запевняли, були необачно заховані в стіжку сіна та згоріли (ДАРО. Ф. Р-30. Оп. 2. Спр. 35: 59-61).

У протоколі СБ Чортківського надрайону (Тернопільщина) стосовно розслідування надуживань учасників боївки “Шури” зазначалося, що 25 березня 1946 р. вони пішли “під маскою більшовиків" в с. Волоковець Борщівського р-ну. Як йшлося в документі: “Тут зайшли до однієї хати...Др. Шура відкрив скриню і забрав гроші, сподні і три метри матеріалу на убрання і шукали за салом, але не знайшли". Після цієї грабіжницької операції “. . .стрільці почали бунтуватися і один з другого насміхатися, що вони розбійники. Пізніше здезертирувало двоє стрільців “Зуб” і “Дубовий” і казали, що ми не підемо грабувати людей” (ДАТО, Ф. формується).

Інколи, розкрадання підпільниками здобутого під час бойових акцій майна, поєднувалася із низкою інших порушень - недотримання конспірації, аморальною поведінкою тощо. Зрештою вони призводили до прикрих “провалів". Колишній співробітник Березнівського райвідділу МДБ Степан Цвіркун згадував, що одну з боївок ОУН їм вдалося схопили без жодного спротиву. Виявилося, що після “експропріації" магазину підпільники залишилися “святкувати” в тому ж селі (Цвіркун, 1981: 4).

Не менш рішуче СБ виявляла та карала таких осіб серед власних співробітників. Зокрема, зберігся протокол внутрішнього розслідування щодо референта СБ Висоцького р-ну ОУН Григорія Сизонюка - “Діброви” від 6 жовтня 1948 р.

У ньому перелічено чимало провин. Серед них пограбування в “бандитський спосіб” магазину кооперації в с. Радчицьк Столинського р-ну Пінської обл. (Білорусія). При цьому Сизонюк населенню заявив: "Ми українські повстанці, а не більшовики. Не бійтесь, за два дні ваша власність вам буде повернена". Проте, реквізованих трьох коней і два вози він не повернув, а виміняв в с. Яцухи Дубровицького р-ну на горілку... На початку січня 1947 р. забрали в кооперативі с. Сітицьк Столинського р-ну декілька літрів горілки та вина, які по дорозі випили. У розмові з “Василем" за вересень 1947 р. висловлювався відносно звітів та організаційних наказів: “Добре їм (зверхникам) в криївках сидіти на всьому готовому і командувати... Не бійся - кожен хоче пережити, а ти наражайся. Була житуха в $45-46$ рр. як нас ніхто не знав і ми нікого”... Після пограбування магазину наказував бойовикам "Максиму” та "Володі": "Нікому не кажіть скільки чого взяли, я сам знатиму як прозвітувати" (ДАРО. Ф. Р-30. Спр 113: 18-19).

За результатами розслідування Революційний трибунал засудив “Діброву” до розстрілу. Вирок щодо нього виконав особисто референт СБ Ковельської округи Анатолій Згаб”юк - “Михайло” (ДАРО. Ф. 2771. Спр. 5035: 32; ГДА СБУ. Ф. 5. Спр. 68227: 25).

29 квітня 1946 р. Чортківський надрайонний тереновий суд ОУН (Тернопільщина) розслідував справу референта СБ Гусятинського р-ну Михайла Мицика - “Ділового”. Арештований есбіст зізнався: "На цьому терені, де я працював, майже в кожному селі мав я для себе дівчину з якими входив в полові зносини, а 
іменно.... Рівно ж розбазарював організаційне майно на свою власну руку, для жінок 3 котрими мав особисті порахунки" (ДАТО, Ф. формується).

Слід зауважити, що при винесені вироку провина не завжди відігравала вирішальну роль. Важливим чинником були обставини вчинення злочину, тогочасні умови діяльності підпілля та інше. Референт СБ Острозького р-ну ОУН Григорій Довбенко - "Юрко" стратив на початку 1946 р. “за розбазарювання продуктів” господарчого Мізоцького рну ОУН “Сулиму” (АУСБУ РО. Ф. П. Спр. 9958: 25). Натомість станичний с. Малий Говилів Теребовлянського р-ну Тернопільської обл. отримав “за крадіж організаційного добра” лише 10 “буків” (ударів палицею) (Літопис УПА, 2006: 456).

Згідно “Дисциплінарного статуту УПА” для повстанців передбачалося два види покарання: смертний вирок та перебування у карному відділі на час до трьох місяців. Тяжким злочином вважалося “шкідництво з метою підірвати міць УПА”, яке каралося розстрілом. Вирок виконували одразу після завершення суду. Впійманим на "крадіжках задля особистої користі” загрожував “карний арешт” або “карний підрозділ” (Сергійчук, 1996: 272-276). Наприклад, 18 жовтня 1943 р. стрільців “Гонту", “Березу” та "Крука" 3 загону УПА Микити Скуби - “Лайдаки” (Рівненщина) покарали по годині “стійки під крісом" за розбазарювання солі (Літопис УПА, 2010: 147). 7 січня 1944 р. стрільцю “Степану” з сотні Михайла Кондрася - "Великана" (Дубенщина) присудили місяць “карного відділу” за крадіжку годинника (Літопис УПА, 1999: 392).

Якщо засуджений повторював злочин, його розстрілювали (Сергійчук, 1996: 277). Зокрема 30 квітня 1945 р. за згаданих обставин своїми колегами був розстріляний бойовик СБ Григорій Ферій - “Крук”. Перед стратою комендант “Тарас" в присутності усієї боївки зачитав йому “карний звіт”. У ньому зазначалося, що перебуваючи 27 лютого 1945 р. при виконанні завдання в школі с. Підгірки (нині в складі м. Калуш ІваноФранківської обл.) “Крук” викрав у однієї з вчительок 150 карбованців. Згодом комендант боївки СБ про це довідався та покарав свого підопічного 25 ударами палицею. При цьому зауважив, що наступного разу за таке розстріляє. Однак “Крук” злегковажив попередженням. Рівно через місяць при виконанні завдання в с. Середнє забрав собі штани, жакет та гроші. При цьому намовляв інших боївкарів, щоб вони мовчали про привласнені речі (ГДА СБУ. Ф. 13. Спр. 376. Т. 54: 11-13).

Нерідко зазначені страти проводили публічно. 9 жовтня 1943 р. Військовопольовий суд Групи УПА “Тури” (Волинська обл.) розглядав справу чотового (взводного) “Аліма”, а також стрільців “Лося” та “Орлика” з відділу “Чуйкевича”. ІІх звинувачували у викраданні майна підрозділу та обміну його на самогон. Ввечері того ж самого дня усіх підслідних розстріляли (Літопис УПА, 1999: 498).

Під час проведення СБ у грудні 1943 р. перевірки відділів УПА “Ясена” (південна Рівненщина) було викрито зловживання сотенного господарчого "Комара". Розслідування встановило, що більшу частину військового майна він роздав своїй родині "так що сотні мало що й залишилося". За згадані злочини “Комар" отримав від Революційного Суду УПА смертний вирок через розстріл. Його безпосереднього начальника - сотенного “Довбенка" покарали доганою з правом реабілітації та відправили командувати “карною сотнею”. Бунчужного “Гонту”, який також фігурував у справі господарчого “Комара", виправдали та повернули на попередню посаду (Микола Андрощук, 2011: 66).

В окремих випадках засуджених до страти могли помилувати. Підставою були особливі заслуги перед підпіллям або “пом'якшуючі” обставини. За свідченнями провідника ОУН Північно-Західного Крайового проводу ОУН Івана Литвинчука “Дубового”, референт СБ Василь Макар - “Безрідний” мав намір в 1943 р. розстріляти “за розтрату організаційного майна" Павла Трофімчука. Однак провідник ОУН на ПЗУЗ Дмитро Клячківський - “Охрім” їх помилував (Літопис УПА, 2006: 1201). Свген 
Липовий - “Макар" свідчив на допиті в СБ про “кумівство” провідника ОУН Заліщицького повіту “Ата”. За крадіжки організаційного майна його 10 квітня 1943 р. зняли $з$ посади та відправили до округи на слідство. Однак жодного покарання за свої злочини “Ат” не отримав, адже його “взяв на поруки” брат - Крайовий провідник ОУН (Літопис УПА, 2006: 458).

Аналізуючи наведені вище факти, варто зауважити, що подібні випадки були в підпілля ОУН та УПА великою рідкістю. Незважаючи на сувору дисципліну та чітку субординацію, в матеріальному забезпеченні керівники не особливо відрізнялися від рядових. Переважно вони ділили із своїми підлеглими їжу та тимчасові помешкання. Наприклад, провідник ОУН на ПЗУЗ Василь Галаса - “Орлан” та його дружина Марія Савчин - "Марічка" зимували 1950 р. в наспіх збудованій криївці поблизу с. Ставок Турійського р-ну Волинської обл. Районний референт технічного ланки ОУН Олексій Ткачук - “Олекса", який впродовж наступних двох років переховувався у тому ж схроні, скаржився своєму керівнику Григорію Грушовцю - "Хомі”: “Краще сидіти у в'язниці, ніж у такій криївці” (АУСБУ ВО. Ф. П. Спр. 8851: 45-46). Згаданий провідник “Орлан” у листі до свого помічника "Карпа" від 1951 р. обурювався, що придбання матеріалу для пошиття штанів той перетворив у “велику справу”. Як зазначав Василь Галаса в листі: "Мені волосся стало дибки, коли я дізнався, що Ви двічі відсилали людину за матеріалом для мене та ще й через колір не купили. Мене від цього взяв сором та обурення. Я такого доручення не давав... Категорично наказую Вам припинити шукати матеріал. Якщо все-таки вже купили, то передайте комусь з друзів. У мене трапилось, що порвалися штани, але я вже собі дістав від хлопців і ходжу. Ні радіо, ні живлення мені не потрібно не купуйте" (ГДА СБУ. Ф. 2. Спр. 2052: 158).

Особливо важкою ситуація була під час вимушеного затягування “зимування”. Невибагливий раціон мешканців криївки тоді урізався до стану фізичного виживання. Усі отримували однакові порції, а поміченим у зловживаннях могла загрожувати негайна смерть. Подібна ситуація трапилася в криївці Головного пропагандиста ОУН Петра Федуна - “Полтави”. Коли підпільники помітили, що кухар “Юрко” кладе собі до каші більше масла, його за вироком “товариського суду” стратили (Вєдєнєєв, Биструхін, 2007: 59-60).

Крім того СБ ретельно стежила за способом життя керівників підпілля. Не лише фінансові зловживання, а й будь-які негідні вчинки сприймалися як підрив репутації ОУН та суворо каралися. Наприклад, за “аморальне життя" 11 жовтня 1945 р. боївкою СБ був розстріляний референт пропаганди надрайону ОУН "Ролянд” (ГДА СБУ. Ф. 13. Спр. 376. Т. 51: 329).

Водночас серед рядових підпільників, особливо вояків УПА, побутувала думка, що співробітники СБ за рахунок службового становища краще одягаються та харчуються. У звіті з політично-виховної роботи при відділах УПА Групи “Енея” (південна Волинь) від 10 грудня 1943 р. зазначалося: “Загально помічається невдоволення повстанців 3 роботи і поведінки працівників запілля, а особливо СБ, теренових боївок та господарчої референтури. Стрільці говорять, що СБ і теренові боївки добре вдягнені, добре взуті, добре їдять, спокійно роз'їжджають по теренах, а до того всього зарозумілі, грубо відносяться до населення і до стрілецтва... І одних і других називають повстанці “тереновими панами" або “тереновими птахами” (ДАРО. Ф. Р-30. Оп. 2. Спр. 33: 8-9). Комендант Рівненського р-ну ОУН скаржився у звіті від 30 жовтня 1943 р., що референт СБ “Дуб” забрав в Українського Червоного Хреста великий санітарний будинок для поранених. Взамін надав їм невеличку хатинку. Свій вчинок пояснював необхідністю розміщення “секретаріату”. Висміюючи чванливість та любов до розкошів співробітників СБ комендант надрайону ОУН називав їх “гусаками” та “султанами” (Літопис УПА, 2007: 586), а чотовий УПА Микола Голод - “яєшниками” та “самогонщиками” (Стецюк, 1992: 82). 
Насправді згадані звинувачення та насмішки не відповідали дійсності. Кожен керівник підпілля, в тому числі референт СБ, періодично подавав своєму очільнику детальну звітність (“касовий звіт”) про використані кошти. Із зібраного та здобутого в бойових операціях вони могли залишити на власні потреби до $25 \%$. Решту передавали вищим проводам, які їх розподіляли в залежності від пріоритетів роботи підпілля (Даниленко, 2006: 14). Зокрема в інструкції для підпільників ОУН Чернівецької округи від 1947 р. зазначалося: “Здобуті гроші чи речі невільно розходувати без відома своїх зверхників. Речей непотрібних для повстанців, забороняється брати від населення. Речі потрібні, заборонено забирати в людей нам прихильних, але бідних. Про кожну забрану річ звітувати вгору” (ГДА СБУ. Ф. 2. Спр. 2010: 369).

Попри чітко налагоджену систему обліку та звітності, траплялися випадки порушень. Документ підпілля ОУН з Чортківського надрайону від травня 1946 р. повідомляє, що “Довбуш” взяв без дозволу від кущового Скала-Подільського р-ну ОУН 10 тисяч крб., “не здавши про це квита та жодного вияснення на що ці гроші забирає” (ДАТО. Ф. формується). У листі провідника ОУН Станіславської округи Михайла Хміля “Весволода" зазначалося: “Мав зустріч з “Влучком”, взяв у нього господарські книги (ще не провірив по квитанціях) і грошей 7150 рублів, які пересилаю Вам. До балансу залишилося 27673 рублі, їх нема ні в касі, ні на території, ні в квитанціях (в тих, які я отримав) i, накінець, про них не знає “Влучко” (Ільницький, 2017: 348). На початку 1946 р. референт СБ Буського надрайону “Ігор” розшукував командира сотні УПА Красненського p-ну Львівської обл. Кравчука Мар'яна - “Малинового”. Отримавши з курінної каси гроші на обмундирування вояків, він разом з сім'єю втік до Польщі, а звідти - в Німеччину (ГДА СБУ. Ф. 2. Спр. 2734: 267).

Слід зауважити, що поодинокі випадки господарських зловживань в середовищі ОУН та УПА не йшли у жодне порівняння з тотальною корумпованістю радянського державного апарату. Численні свідчення про неї збереглися в документах підпілля. У суспільно-політичному звіті з Бережанщини (Тернопільщина) за квітень 1947 р. зазначається: "Хабарництво, підкупництво має місце у всіх большевицьких установах та на всіх ділянках життя. Це як вище наведено проводять найбільш упрівелейовані радянські люди - партійні. Придержуються большевики народної приказки - не помажеш, не поїдеш" (ДАТО, Ф. формується).

Підпілля ОУН активно використовувало ці факти з пропагандистською метою. Радянських корупціонерів вони вважали корисними для повалення режиму, а тому ставилися до них поблажливо. У квітні 1947 р. учасники боївки СБ Прокопа Штандера - “Тудзика" в формі прикордонників випадково зустріли нетверезого лісника з с. Світязь Шацького р-ну Волинської обл. Гадаючи, що перед ним радянські військові, він почав скаржитися, мовляв селяни крадуть в нього ліс. На це співробітники СБ, які добре знали, що лісник насправді обкрадає державу, лише посміялися (АСБУ ВО. Ф. П. Спр. 8040: 80).

Більше того, корумпованість радянського державного апарату використовувалася підпіллям ОУН як один із ефективних засобів діяльності. Шляхом підкупу чиновників вони здобували необхідні товари, фальшиві документи, а інколи й звільняли ув'язнених товаришів. Так, Крайовий провідник ОУН Степан Янішевський - “Далекий”, намагався в лютому 1948 р. за хабар визволити з тюрми свою дружину Галину Регезу (ГДА СБУ. Ф. 5. Спр. 67426. Т. 5: 193-194). За його завданням підпільниця Віра Малецька зв'язалася з військовим лікарем Пожарським, росіянином за національністю. За “подарунок” в 7 тисяч крб. він обіцяв зімітувати невиліковне захворювання арештантки. Водночас “компетентно” зауважив, що позитивного результату справи не гарантує (ГДА СБУ. Ф. 5. Спр. 67426. Т. 2: 77, 82). Учасник Львівської юнацької мережі ОУН Євген Максимів за хабар в 4 тисячі карбованців отримав восени 1945 р. 
від співробітника Шевченківського райвійськкомату (в званні лейтенанта), фіктивне звільнення від служби в армії “через інвалідність” (ГДА СБУ. Ф. 2. Спр. 1785: 286). Учасниця підпілля ОУН Ірина Приймак - “Оленка” з м. Станіславів, за хабар в 10 тисяч карбованців, вступила до Одеського медичного інституту. Гроші між собою розділили лікар з приймальної комісії, декан факультету та приставлений “наглядати” за згаданим інститутом капітан МДБ (ГДА СБУ. Ф. 2. Спр. 2011: 102).

Окремим напрямком антикорупційної діяльності СБ була ії̈ робота в емігрантському середовищі Закордонних центрів ОУН. На відміну від умов “діючого підпілля” України, на "Вільний світ", тобто країни Західної Свропи та Північної Америки, не поширювалися радикальні методи “революційної боротьби”. Діяльність СБ мала обмеженіші масштаби та намагалася не виходити за рамки діючого у згаданих країнах законодавства.

Головний напрямок антикорупційної роботи в цей час зосередився на розслідувані фінансових зловживань посадових осіб, які мали доступ до організаційних кас. Чимало інформації про це містять свідчення референта СБ Закордонних частин (далі - ЗЧ) Мирона Матвієйка - "Усміха". Однак, через його заангажованість їх достовірність викликає сумніви. Ймовірно, на допитах Матвієйко хотів очорнити зверхників, рятуючи своє життя. Попри те, потрібно розглянути й це джерело. Зокрема, "Усміх" розповідав, що у розкраданні організаційного майна підозрювався фінансовий референт ЗЧ ОУН Микола Климишин - “Непоборний”. Від попередника йому дісталося більше 5 млн. німецьких марок та різні коштовності (Вєдєнєєв, Биструхін, 2007: 231). Однак своєму наступнику Євгену Гарабачу він залишив лише 2 тисячі марок. Розслідування встановило, що зниклі гроші Климишин витрачав на власні потреби. Зокрема щомісячно виділяв на отримання своєї сім'ї близько 15 тис. німецьких марок. Для порівняння, іншим оунівцям за той же час видавалося не більше 300 марок. Забезпечення ж усієї місячної роботи референтур ЗЧ ОУН в Мюнхені обходилося в суму від 10-ти до 15-ти тисяч марок. Тобто менше ніж утримання сім'ї Климишина. Цей факт обурював співробітників СБ, які нібито вимагали в Степана Бандери дозволу на арешт злочинця. Одначе їм було відмовлено (ГДА СБУ. Ф. 6. Спр. 56232: 54-55). За сумнівними свідченнями "Усміха" фінансовими зловживаннями “грішили" й інші керівники підпілля ОУН за кордоном. Генеральний секретар зовнішніх справ УГВР Микола Лебедь - "Максим Рубан” присвоїв собі браслет з брильянтами, який належав підслідному кур'єру ЗЧ ОУН Василю Чижевському “Демиду”. Продав його в Італії, а отримані гроші використав на власні потреби (Степан Бандера, 2009: 71). Куратор військового сектору ЗЧ ОУН Степан Ленкавський - “Коваль” таємно взяв з організаційної каси гроші на придбання квартири (Вєдєнєєв, Биструхін, 2007: 396). Існують відомості, що й окремі есбісти не залишилися осторонь від корупційних зловживань. За однією із версій референт СБ у таборі для переміщених осіб м. Ляндсгут (Східна Баварія) Павло Микитин, емігруючи весною 1950 р. до США, прихопив із собою гроші з організаційної каси (ГДА СБУ. Ф. 1. Спр. 1207: 180).

Тематично подібною до свідчень Мирона Матвієйка є пропагандистська книга спогадів касира референтури Крайового зв”язку “К-З” ЗЧ ОУН Степана Джугала. У ній він звинувачував в фінансових зловживаннях Степана Бандеру, Степана Ленкавського, Омеляна Коваля та Осипа Тюшка. За версією Джугала, останній жартома інтерпретував слово “демократія" як “де мож, кради”. Як зазначалося у “спогадах", на утримання 10 службовців бюро ЗЧ ОУН в Мюнхені виділялося щомісячно 5 тисяч марок. Інші 23 тисячі витрачали на свої потреби 6 членів проводу (Джугало, 1973: 10-42).

Скромна підтримка “союзників” у поєднанні з проявами корупції призвели до скрутного матеріального становища в мережі ЗЧ ОУН (Степан Бандера, 2009: 342). Восени 1948 p. pеферент СБ ЗЧ ОУН в Німеччині “Свген” пропонував Бандері здійснити на черговій сесії Асамблеї ООН в Парижі замах на представника СРСР - Андрія 
Вишинського (горезвісного державного обвинувача) (Вєдєнєєв, Биструхін, 2007: 232). Однак на той час необхідних коштів для реалізації задуманого не знайшлося (Степан Бандера, 2009: 184). Зрештою, за свідченнями "Усміха", корупція в керівництві ЗЧ ОУН набула зовнішнього розголосу. Зокрема в Баварії поліція арештувала з фальшивими доларами учасників кур'єрської групи, які готувалися для відправлення в Україну. Фінансування цієї операції під кодовою назвою “Богун” йшло від американців. Тому, дізнавшись, що справжні гроші хтось підмінив, вони розгнівались на відповідальних осіб з ЗЧ ОУН (ГДА СБУ. Ф. 6. Спр. 56232: 177). Ймовірно, цей випадок призвів до того, що надалі Розвідувальне управління Міністерства оборони США (Defense Intelligence Agency) підтримувало Закордонне представництво УГВР, а ЗЧ ОУН орієнтувалося на співпрацю з Таємною службою розвідки Великобританії (Secret Intelligence Service) (ГДА СБУ. Ф. 6. Спр. 56232: 24-25).

Останній випадок корупційного скандалу в середовищі ЗЧ ОУН органи КДБ зафіксували наприкінці 1971 р. Зокрема, референт СБ Іван Кашуба - “Чад" гостро критикував вище організаційне керівництво - подружжя Ярослава та Ярослави Стецьків. Серед інших звинувачень він закидав їм розтрату організаційних коштів. У результаті Кашуба був відсторонений від своєї посади, а місце референта СБ зайняв його заступник Степан Мудрик - “Мечник”. Однак покарати суворіше Кашубу не було змоги. На його сторону стало СБ Теренового проводу Великобританії, яка погрожувала виходом Союзу Українців Британії зі складу ЗЧ ОУН (ГДА СБУ. Ф. 16. Спр. 1013: 278-279).

Підсумовуючи протидію СБ господарсько-фінансовим зловживанням в підпіллі ОУН, можна виділити кілька притаманних їй особливостей. Даний напрямок роботи ніколи не виходив на чільне місце. Він завжди залишався одним із аспектів більш важливих спрямувань діяльності СБ. Головним об'єктом антикорупційних розслідувань були господарчі та фінансові референти, які розпоряджалися організаційними коштами. Стосовно підозрюваних проводився збір доказової бази, відповідні слідчі та судові дії. Покарання засуджених залежало від важкості злочинів та обставин вчинення. Стосовно виявлених корупціонерів, переважно, застосовували смертну кару через розстріл. При цьому вирок міг бути виконаний за будь-яких зручних умов. Водночас суттєвих стягнень зазнавали керівники підпілля, які допустили корупційні злочини в підзвітній їм ділянці. Дрібні господарчі зловживання карали пониженням у посаді, фізичними навантаженнями під час служби або публічним побиттям.

Лiтература:

АУСБУ ВО - Архів Управління Служби безпеки у Волинській області.

Вєдєнєєв, Биструхін, 2006 - Вєдєнєєв Д., Биструхін Г. “Повстанська розвідка діє точно й відважно...”. Документальна спад-щина підрозділів спеціального призначення Організації українських націо-налістів та Української повстанської армії. 1940-1950-ті роки. Київ: К.І.С., 2006. 568 с.

Вєдєнєєв, Биструхін, 2007 - Вєдєнєєв Д., Биструхін Г. Двобій без компромісів. Протиборство спецпідрозділів ОУН та радянських сил 1945-1980-ті рр. Київ: Генеза, 2007. 568 с.

ГДА СБУ - Галузевий державний архів Служби безпеки України

Даниленко, 2006 - Даниленко В. Бофони у фінансово-господарській діяльності ОУН і УПА // Історичний журнал. 2006. № 3. С. 3-16.

ДАРО - Державний архів Рівненської області

ДАТО - Державний архів Тернопільської області

Джугало, 1973 - Джугало С. За лаштунками вертепу ЗЧ ОУН. Київ: Україна, 1973. 44 с.

Ільницький, 2017 - Ільницький В. Організація господарського та фінансового забезпечення діяльності Карпатського краю ОУН // Дрогобицький краєзнавчий збірник. Дрогобич: Посвіт, 2017. С. 340-356.

Ковальчук, 2006 - Ковальчук В. Діяльність ОУН(б) і Запілля УПА на Волині й південному Поліссі (1941-1944 рр.). Львів-Торонто: Літопис УПА, 2006. Т. 7.512 с.

Литвин, 2012 - Литвин М. Фінансово-господарська діяльність ОУН і УПА // Україна: культурна спадщина, національна свідомість, державність. Львів, 2012. Вип. 22. С. 297-305.

Літопис УПА, 1999 - Літопис УПА. Нова серія / упоряд. О. Вовк, І. Павленко. Т. 2: Волинь і Полісся: УПА та запілля. 1943-1944. Київ-Торонто: Літопис УПА, 1999.- 724 с. 
Літопис УПА, 2006 - Літопис УПА. Нова серія / упоряд. О. Вовк, С. Кокін. Т. 8: Волинь, Полісся, Поділля: УПА та запілля. 1944-1946. Київ-Торонто, 2006. 1448 с.

Літопис УПА, 2006 - Літопис УПА. Основна серія / ред. П. Потічний. Т. 43: Боротьба з агентурою: Протоколи допитів Служби безпеки ОУН на Тернопільщині. 1946-1948. Торонто-Львів, 2006. 1332 с.

Літопис УПА, 2007 - Літопис УПА. Нова серія / упоряд. В. Ковальчук. Т. 11: Мережа ОУН(б) і запілля УПА на території ВО “Заграва”, “Турів”, “Богун” (серпень 1942 - грудень 1943). Київ-Торонто, 2007.848 с. Літопис УПА, 2007 - Літопис УПА. Основана серія / ред. П. Потічний. Т. 46: Боротьба з агентурою: протоколи допитів Служби безпеки ОУН в Тернопільщині. 1946-1948. Книга 3. Торонто-Львів, 2007. 336 с. Літопис УПА, 2009 - Літопис УПА. Нова серія / упоряд. В. Мороз, О. Вовк. Т. 13: Воєнна округа

“Буг”. 1943-1952. Київ-Торонто, 2009. 1232 с. Літопис УПА, 2010 - Літопис УПА. Нова серія / упоряд. В. Ковальчук, I. Марчук. Т. 14: УПА і запілля на ПЗУЗ. 1943-1945. Київ-Торонто, 2010. 640 с. Літопис УПА, 2012 - Літопис УПА. Нова серія / упоряд. С. Волянюк. - Т. 20: Воєнна округа УПА

“Лисоня”. 1943-1952. Київ-Торонто, 2012.848 с.

Літопис УПА, 2013 - Літопис УПА. Нова серія. / упоряд. М. Романюк. Т. 23: Золочівська округа

ОУН: Документи і матеріали референтури СБ. 1944-1951. Київ-Торонто, 2013. 1320 с.

Матеріали, 2003 - Матеріали та документи Служби безпеки ОУН (Б) у 1940-х рр. / упоряд. О. Лисенко,

I. Патриляк. Київ, 2003.253 с.

Микола Андрощук, 2011 - Микола Андрощук - "Вороний”. Записки повстанця / ред. I. Марчук. Торонто-Львів: Літопис УПА, 2011. Кн. 13.127 с.

Мірчук, 2007 - Мірчук П. Нарис історії ОУН. 1920 - 1939 роки. Київ: Українська видавнича спілка,

2007. $1006 \mathrm{c}$.

Ільницький, Особистий архів - Особистий архів доктора історичних наук Ільницького В.І. (м. Дрогобич). 1996. 496

Сергійчук, 1996 - Сергійчук В. ОУН-УПА в роки війни. Нові документи і матеріали. Київ: Дніпро,

Степан Бандера, 2009 - Степан Бандера у документах радянських органів державної безпеки (1939-

1959) / ред. рада: В. В’ятрович, С. Кокін, В. Сергічук, Н. Сердюк. Київ: ПП Сергійчук М.І., 2009. Т. 3. 647 с. Стародубець, 2006 - Стародубець Г. Українське повстанське запілля (друга пол. 1943 - поч. 1946

років). Тернопіль: Підручники і посібники, 2006. 527 с.

Стародубець, 2008 - Стародубець Г. Генеза українського повстанського запілля. Тернопіль: Підручники і посібники, 2008. 464 с.

Стецюк, 1992 - Стецюк Г. Чорні дні Волині. Володимир-Волинський: Світязь, 1992. 127 с.

Трофимович, Антонюк, 2009 - Трофимович В., Антонюк Я. Діяльність Служби безпеки ОУН(б)

щодо матеріального забезпечення оунівського підпілля Волині і Полісся. 1945-1951 рр. // Наукові записки Національного університету “Острозька академія”: Історичні науки. Острог, 2009. С. 157-173.

Цвіркун, 1981 - Цвіркун С. Пам’ять не прощає // Ленінським шляхом. 1981. 19 листопада. С. 4.

\section{References:}

AUSBU VO - Arkhiv Upravlinnia Sluzhby bezpeky u Volynskii oblasti [Archive of the Office of the Security Service in the Volyn region]. [in Ukrainian].

Viedienieiev, Bystrukhin, 2006 - Viedienieiev D., Bystrukhin H. "Povstanska rozvidka diie tochno y vidvazhno...". Dokumentalna spadshchyna pidrozdiliv spetsialnoho pryznachennia Orhanizatsii ukrainskykh natsionalistiv ta Ukrainskoi povstanskoi armii. 1940-1950-ti roky ["The insurgent intelligence operates precisely and courageously...". The documentary legacy of special intelligence units of the Organization of Ukrainian Nationalists and the Ukrainian Insurgent Army. 1940-1950s”]. Kyiv: K.I.S., 2006. 568 s. [in Ukrainian].

Viedienieiev, Bystrukhin, 2007 - Viedienieiev D., Bystrukhin H. Dvobii bez kompromisiv. Protyborstvo spetspidrozdiliv OUN ta radianskykh syl 1945-1980-ti rr. [Aduel without compromises. The confrontation between the OUN Security Service subdivisions and the Soviet intelligence forces. 1945 - 1980s]. Kyiv: Geneza, 2007. 568 s. [in Ukrainian].

HDA SBU - Haluzevyi derzhavnyi arkhiv Sluzhby bezpeky Ukrainy [Sectoral State Archive of Security Service of Ukraine]. [in Ukrainian].

Danylenko, 2006 - Danylenko V. Bofony u finansovo-hospodarskii diialnosti OUN i UPA [Bofony in financial and economic activities of the OUN and UPA] // Istorychnyi zhurnal. 2006. № 3. S. 3-16. [in Ukrainian]. DARO - Derzhavnyi arkhiv Rivnenskoi oblasti [State archive of Rivne region]. [in Ukrainian].

DATO - Derzhavnyi arkhiv Ternopilskoi oblasti [State archive of Ternopil region]. [in Ukrainian].

Dzhuhalo, 1973 - Dzhuhalo S. Za lashtunkamy vertepu ZCh OUN [Behind the scenes of a ZCh OUN nap]. Kyiv: Ukraina, 1973. 44 s. [in Ukrainian].

Ilnytskyi, 2017 - Ilnytskyi V. Orhanizatsiia hospodarskoho ta finansovoho zabezpechennia diialnosti Karpatskoho kraiu OUN [Organization of the economic and financial support of the OUN of the Carpathian region] // Drohobytskyi kraieznavchyi zbirnyk. Drohobych: Posvit, 2017. S. 340-356. [in Ukrainian].

Kovalchuk, 2006 - Kovalchuk V. Diialnist OUN(b) i Zapillia UPA na Volyni y pivdennomu Polissi (19411944 rr.) [Activities of the OUN (b) and Zapilya UPA in Volyn and southern Polissya (1941-1944)]. Lviv-Toronto: Litopys UPA, 2006. T. 7. 512 s. [in Ukrainian]. 
Lytvyn, 2012 - Lytvyn M. Finansovo-hospodarska diialnist OUN i UPA [Financial and economic activity of the OUN and UPA] // Ukraina: kulturna spadshchyna, natsionalna svidomist, derzhavnist. Lviv, 2012. Vyp. 22. S. 297-305. [in Ukrainian].

Litopys UPA, 1999 - Litopys UPA. Nova seriia / uporiad. O. Vovk, I. Pavlenko. T. 2: Volyn i Polissia: UPA ta zapillia. 1943-1944 [Volyn and Polissya: UPA and Zapilya. 1943-1944]. Kyiv-Toronto: Litopys UPA, 1999. - 724 s. [in Ukrainian].

Litopys UPA, 2006 - Litopys UPA. Nova seriia / uporiad. O. Vovk, S. Kokin. T. 8: Volyn, Polissia, Podillia: UPA ta zapillia. 1944-1946 [Volyn, Polissya, Podillya: UPA and Zapilya. 1944-1946]. Kyiv-Toronto, 2006. 1448 s. [in Ukrainian].

Litopys UPA, 2006 - Litopys UPA. Osnovna seriia / red. P. Potichnyi. T. 43: Borotba z ahenturoiu: Protokoly dopytiv Sluzhby bezpeky OUN na Ternopilshchyni. 1946-1948 [The fight against the agents: Protocols of interrogations of the OUN Security Service in Ternopil region. 1946-1948]. Toronto-Lviv, 2006. 1332 s. [in Ukrainian]. Litopys UPA, 2007 - Litopys UPA. Nova seriia / uporiad. V. Kovalchuk. T. 11: Merezha OUN(b) i zapillia UPA na terytorii VO "Zahrava", "Turiv", "Bohun" (serpen 1942 - hruden 1943) [The network of the OUN (b) and Zapilya UPA on the territory of VO "Zahrava", "Turiv", "Bohun" (August 1942 - December 1943)]. KyivToronto, 2007. 848 s. [in Ukrainian].

Litopys UPA, 2007 - Litopys UPA. Osnovana seriia / red. P. Potichnyi. T. 46: Borotba z ahenturoiu: protokoly dopytiv Sluzhby bezpeky OUN v Ternopilshchyni. 1946-1948 [The fight against the agents: Protocols of interrogations of the OUN Security Service in Ternopil region. 1946-1948]. Knyha 3. TorontoLviv, 2007. 336 s. [in Ukrainian].

Litopys UPÁ, 2009 - Litopys UPA. Nova seriia / uporiad. V. Moroz, O. Vovk. T. 13: Voienna okruha "Buh". 1943-1952 [Military district "Buh". 1943-1952]. Kyiv-Toronto, 2009. 1232 s. [in Ukrainian].

Litopys UPA, 2010 - Litopys UPA. Nova seriia / uporiad. V. Kovalchuk, I. Marchuk. T. 14: UPA i zapillia na PZUZ. 1943-1945 [UPA and Zapilya on PZUZ. 1943-1945]. Kyiv-Toronto, 2010. 640 s. [in Ukrainian].

Litopys UPA, 2012 - Litopys UPA. Nova seriia / uporiad. S. Volianiuk. - T. 20: Voienna okruha UPA "Lysonia". 1943-1952 [The UPA military district "Lysonya". 1943-1952]. Kyiv-Toronto, 2012. 848 s. [in Ukrainian]. Litopys UPA, 2013 - Litopys UPA. Nova seriia. / uporiad. M. Romaniuk. T. 23: Zolochivska okruha OUN: Dokumenty i materialy referentury SB. 1944-1951 [Zolochiv OUN district: Documents and materials of the Security Service intelligence. 1944-1951]. Kyiv-Toronto, 2013. 1320 s. [in Ukrainian].

Materialy, 2003 - Materialy ta dokumenty Sluzhby bezpeky OUN (B) u 1940-kh rr. [Materials and documents of the OUN (B) Security Service in the 1940's.] / uporiad. O. Lysenko, I. Patryliak. Kyiv, 2003. 253 s. [in Ukrainian]. Mykola Androshchuk, 2011 - Mykola Androshchuk - "Voronyi". Zapysky povstantsia [Mykola Androshchuk - "Voronyi". Notes of an insurgent.] / red. I. Marchuk. Toronto-Lviv: Litopys UPA, 2011. Kn. 13. 127 s. [in Ukrainian].

Mirchuk, 2007 - Mirchuk P. Narys istorii OUN. 1920-1939 roky [An essay on the OUN history 1920-1939]. Kyiv: Ukrainska vydavnycha spilka, 2007. 1006 s. [in Ukrainian].

Ilnytskyi, Osobystyi arkhiv - Osobystyi arkhiv doktora istorychnykh nauk Ilnytskoho V.I. (m. Drohobych) [Personal archive of Dr of Historical Sciences V. I. Ilnytskyi (Drohobych)].

Serhiichuk, 1996 - Serhiichuk V. OUN-UPA v roky viiny. Novi dokumenty i materialy [OUN-UPAduring the war years. New documents and materials]. Kyiv: Dnipro, 1996. 496 s. [in Ukrainian].

Stepan Bandera, 2009 - Stepan Bandera u dokumentakh radianskykh orhaniv derzhavnoi bezpeky (19391959) [Stepan Bandera in the documents of the Soviet security service organs (1939-1959)] / red. rada: V. Viatrovych, S. Kokin, V. Serhichuk, N. Serdiuk. Kyiv: PP Serhiichuk M.I., 2009. T. 3. 647 s. [in Ukrainian].

Starodubets, 2006 - Starodubets H. Ukrainske povstanske zapillia (druha pol. 1943 - poch. 1946 rokiv) [Ukrainian insurgent Zapilya (second half of 1943 - early 1946)]. Ternopil: Pidruchnyky i posibnyky, 2006. 527 s. [in Ukrainian].

Starodubets, 2008 - Starodubets H. Heneza ukrainskoho povstanskoho zapillia [Genesis of the Ukrainian Insurgent Zapilya]. Ternopil: Pidruchnyky i posibnyky, 2008. 464 s. [in Ukrainian].

Stetsiuk, 1992 - Stetsiuk H. Chorni dni Volyni [Black days of Volyn]. Volodymyr-Volynskyi: Svitiaz, 1992. 127 s. [in Ukrainian].

Trofymovych, Antoniuk, 2009 - Trofymovych V., Antoniuk Ya. Diialnist Sluzhby bezpeky OUN(b) shchodo materialnoho zabezpechennia ounivskoho pidpillia Volyni i Polissia. 1945-1951 rr. [The OUN (b) Security Service participation in the material support of the OUN underground on Volyn and Polissya territories. 1945-1951] // Naukovi zapysky Natsionalnoho universytetu "Ostrozka akademiia": Istorychni nauky. Ostroh, 2009. S. 157-173. [in Ukrainian].

Tsvirkun, 1981 - Tsvirkun S. Pamiat ne proshchaie [Memory does not forgive] // Leninskym shliakhom. 1981. 19 lystopada. S. 4. [in Ukrainian].

Отримано 12.10.2018 